John R.L. Moxon

\title{
Peter's Halakhic Nightmare
}

The »animal« vision of Acts 10:9-16 in Jewish and Graeco-Roman Perspective

[Petrus' halachischer Albtraum. Apg 10,9-16 aus jüdischer und griechisch-römischer Perspektive.]

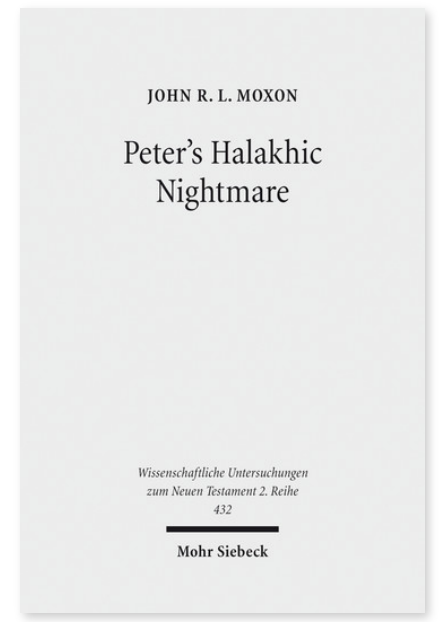

2017. XXV, 638 Seiten. WUNT II 432

ISBN 978-3-16-153542-0

DOI 10.1628/978-3-16-153542-0

eBook PDF 149,00€

ISBN 978-3-16-153301-3

fadengeheftete Broschur 149,00€
Veröffentlicht auf Englisch.

Wollte Lukas durch die Vision des Petrus in Apg 10, in der Gott ihm befahl »unreine Tiere« zu essen die Auflösung der jüdischen Gebote andeuten? Während die Wissenschaft über Quellen, inkonsistente Redaktion und die spätere Rezeption diskutiert haben, wurde es versäumt, die neuartige Verwendung einer Art Sündenangst-Traum zu bemerken. John Moxon zeigt, wie Lukas durch Einbindung solch lebensnaher Leitmotive dem Begriff »Offenbarung « eine neue und deutlich psychologische Richtung gibt, die wahrscheinlich ähnliche Entwicklungen in der griechisch-römischen Biographie imitiert. Wenn die Vision eine rechtswidrige Übergabe von Abscheu innerhalb einer übertriebenen Halacha der Trennung aufdeckt, sind ihre Ziele Vorurteil und Unvereinbarkeit, nicht die Kluft zwischen Juden und Heiden als solche, wie auch der ironische Kontrast zum frommen Kornelius unterstreicht.

John R.L. Moxon Born 1960; 1990 DPhil, University of Oxford; 2011 PhD University of Durham; 2011-14 Director of Studies, Mattersey Hall College; since 2014 Senior Lecturer, Dept. Humanities, Roehampton University.

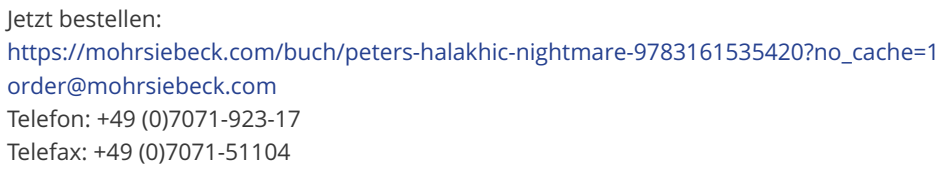

